\title{
The Original Risk: Overtheologizing Ethics and Undertheologizing Sin
}

\author{
DENIS MÜLLER \\ Faculty of Protestant Theology, University of Lausanne, Lausanne, Switzerland
}

The project of articulating a theological ethics on the basis of liturgical anthropology is bound to fail if the necessary consequence is that one has to quit the forum of critical modern rationality. The risk of Engelhardt's approach is to limit rationality to a narrow vision of reason.

Sin is not to be understood as the negation of buman boliness, but as the negation of divine boliness. The only way to renew theological etbics is to understand sin as the anthropological and ethical expression of the biblical message of the justification by faith only.

Sin is therefore a secondary category, which can only by interpreted in light of the positive manifestation of liberation, justification, and grace. The central issue of Christian ethics is not ritual purity or morality, but experience, confession and recognition of our own injustice in our dealing with God and men.

Keywords: bioethics, justification by faith, rationality, sin, disease, theological ethics

\section{SOME FUNDAMENTAL QUESTIONS}

Our contribution addresses some theological and ethical affirmations developed in the earlier issue of this journal on "Sin in Bioethics" (vol. II, no. 2) Our main theoretical interest is not primarily directed to the problem of sin and disease, but to the more fundamental and formal questions of how to understand and interpret theological ethics in open and critical discussion with moral philosophy (see Müller, 2001a, 2001b, 2002a, 2002b). But we

Address correspondence to Denis Müller, Professeur ordinaire, Université de Lausanne, Faculté de théologie et de sciences des religions, Anthropole, 1015 Lausanne, Switzerland. E-mail: Denis.Muller@unil.ch 
will also assume that the way in which we distinguish sin and disease (taking care to neither confuse nor separate the two) is a good test for proving the adequacy of our theoretical presuppositions.

On the theoretical, more fundamental level, both theological and philosophical, I consider, alas, the basic presuppositions of my good old friend Tris Engelhardt, as well as some of those of Corinna Delkeskamp-Hayes in her introduction to the earlier issue of Christian Bioethics, to be misguided and wrong from the very beginning. Corinna Delkeskamp-Hayes can be right when she says:

By affirming the centrality of concerns with sin, an authentic Christian bioethics reminds all concerned that there is a point of ultimate orientation: God. The good, the right, the virtuous and all concerns with human flourishing are thus placed in terms of a pursuit of the Holy and orientation towards the Trinity. (2005, p. 123)

But that does not support a liturgical or soteriological foundation for theology and theological ethics. Of course, I am not saying that what it does imply concerning the Christian life, holiness and so on is untrue or unhelpful. As a reformed, Presbyterian Christian and theologian, I am quite prepared and open to include in my own way of thinking some of the existential, pastoral, and spiritual consequences that their theological approach tries to assert and to illuminate. But Engelhardt and Delkeskamp-Hayes are misguided when they affirm, on a theological level, that theology should start with a liturgical foundation. Liturgy is only a consequence and an expression of faith and can therefore not be considered as a theoretical foundation of theology, understood as rational and argumentative intellectus fidei. Of course I know that my disagreement is deeply rooted in the different ways in which we understand theology, noetic knowledge, and the connection between faith, reason, and theological rationality. As a Protestant thinker, formed in the postcritical and dialectical tradition of Luther, Calvin, Schleiermacher, Barth, Bultmann, and Tillich (with no consideration here of their obvious deep internal differences and disagreements) (see Müller, 1999, 2000, 2005), I remain deeply convinced of three basic presuppositions: 1) Christian faith has to do with a positive assumption (in the sense of both acceptance and integration $)^{1}$ of human and creational realities; in this sense, as we will see, sin will never be able to destroy the creational basis of the Christian faith; 2) Theology is not a negation of reason and rationality but depends on a critical use of reason and rationality. Therefore it would be a great mistake to oppose the noetic cognition of faith to the rational intelligence of faith within academic theology. 3) Theological ethics is necessarily, from its very beginning, a critical reflection on the potentially universal meaning of faith for human life and actions. 
From my own point of view, the problem with Engelhardt's critique of the secular modern project consists in his exaggeration of the negatives sides of this project. Modernity is not interpreted by Engelhardt in a sufficiently differentiated and subtle way; it is subjected to a caricaturing oversimplification, which reminded me of the way in which the late Pope John Paul II managed to reduce all manifestations of the modern world to a "culture of death." Engelhardt's critical assessment, to be sure, is justified in view of exaggerated affirmations of atheism and anticlericalism, as these can be found today in France, for example in Michel Onfray's very popular but also very badly informed and badly written book Traité d'athéologie (2005). But Engelhardt does not capture the problem at its root. Our philosophical and theological challenge today is not to simply oppose immanence and transcendence, as Engelhardt and other contemporary authors do (for instance Stanley Hauerwas) (see Müller, 2002b), but 1) to understand why the modern world has come to think of immanence as a radical enemy of transcendence and transcendence as radical closed-ness to immanence; 2) to become able to interpret immanence itself as posing the question of transcendence, and transcendence as a possible critical interpretation and dialectical assumption (Aufhebung, see note 1) of the very goal (telos) of immanence (Müller 2002b; Holderegger, Müller, et al., 2002, p. 25-42).

Why should it be absolutely necessary to conclude, with Engelhardt, that "within the horizon of the immanent, sound rational argument cannot establish what these canons are" [Christian Bioethics 11, p. 22] (i.e. the canons of moral judgment)? Such a claim implies that all rational and selfcritical theology (or philosophy!) ought to lay down its (their) own canons, very much in the way in which authors like Engelhardt (2000) or Stanley Hauerwas (in his interpretation of Karl Barths' theology, 2001) seem to believe they effectively did. But it is not enough to oppose Christian witness-giving to theological rationality, as Hauerwas does. Before one can contend that every humanistic-rational understanding of immanence leads to a rebuttal of every transcendence, a more subtle and fair analysis of what immanence really means and offers seems to be necessary. Not every understanding of immanence leads to such an elimination of any kind of transcendence. I can agree with Engelhardt and Hauerwas (as well, I could agree from within the tradition of Karl Barth's thought), when they consider that a certain interpretation of immanence in the framework of a certain view of modernity leads to a frontal opposition to every kind of transcendence. But I would surely not approve and follow them, when and if they identify modernity as a whole with a pure negation of any transcendence.

I would indeed contend, on a theological as well as on a philosophical level, that there never will exist any definitive canon of modern thought. On the other hand, I also submit that neither a well-formed theology nor a wellformed philosophy should restrict itself to presenting their own, as if merely 
provisional, conclusions or theses as merely well-formed and well-construed proposals of truth.

As we all well know, theological ethics is as much divided into different approaches as is secular ethics. Therefore, I do not think that the argument from the internal division within the secular project of grounding and orienting ethics to the untenability of this project is convincing. The real problem lies in the cultural, social, historical and epistemological evidence for the fact that all modern projects, whether secular or religious, atheistic/ agnostic or Christian, are hampered by internal divisions, contradictions and oppositions. Here lies the main difficulty for all conservative-traditional attempts to go back to "the truths of before": no philosophy, no theology can be effective and convincing nowadays without accepting the painful, but inescapable, experience of division. That means that no Christian theology and no theological ethics are possible today, unless the challenge of the modern experience and postmodern hesitations are confronted and struggled with. A valid grasp of life, sin, wrongness and goodness, justice and injustice requires a critical discussion, but also a serious acceptance of modernity and postmodernity, or, if you prefer, of the multicolored and polyvalent aspects of our world, life and experience today. I fully agree with Tris Engelhardt (2005) that moral consensus can be and very often really is an illusion. But it would also be a terrible and deceptive illusion to believe that the Christian approach to ethics or bioethics could solve this problem. On the contrary, the unavoidable clash of different faiths, religions and theologies in the public debate on ethical issues enhances this division of thoughts and deepens the difficulty of finding solutions. Of course, on the other hand, this is also no reason to revert to an illusory minimum of secular values, as many contemporary authors think, especially in secular bioethics. The patent clash is only a sign that ethics will always be complex (see Morin, 2004) and that theological ethics has always to do with a dialectical complexification of this complexity! In other words, we must not only be conscious that diversity will always persist, but we must also recognize that theological ethics makes that secular complexity more and more complex: Christian faith does not give us simple answers and solutions but makes ethical decision more difficult and more challenging.

We should not be afraid of that. On the contrary, this challenge is exciting and liberating, because its helps us to renounce all will to power and all spiritual arrogance. It is exciting, because it obliges us to enter into real and difficult discussions with proponents of all kinds of secular and religious ethics. But it is also liberating, because it frees us of all the temptations that induce us to think, as Christians and as theologians, that our theological position protects us from any critical discussion conducted with rational arguments. In the 1970s, some German theologians (for instance Trutz Rendtorff and Wolfhart Pannenberg) appropriately questioned what they called "Positionalität," i.e. an intellectual attitude of positionalism, ${ }^{2}$ which 
claims someone's personal faith or some theologian's theory as absolute foundation of theology. Their adversaries at that time were Karl Barth's dialectical theology and even Rudolf Bultmann's existential theology and hermeneutics. Today, North American authors like Engelhardt and Hauerwas seem to engage in the same kind of positionalism. Surely they are not necessarily arrogant on the personal level, but the way they conceive of their theological work or their affirmation of the Christian truth looks very much like an arrogant, and also naïve, positionalism.

Theological morality and bioethics are plural as well, not only on the descriptive level, but also on the normative one. This is the case, it must be, and will always remain so. Theology should not try to reduce, but to integrate its own plurality. Even invoking God as a foundation for such morality and bioethics does not guarantee, in advance, any transcendental unification of ethics-unless, of course, one adopts the position of the traditional Christian believer, as Engelhardt does. But the problem with this position lies precisely in the fact that, because it remains both traditional and positional, it is not able to secure the critical level one needs to reach if one wants to really face the dilemmas of modern and postmodern rationality.

The position of the traditional Christian believer only works in and for a traditional world, which simply no longer exists.

Lets us be more clear. Of course this "traditional world" still exists in the head, in the heart and in the spiritual world of their fans. But for theology it is never enough to remain just a member of one's fans' club. I am a fan of soccer, and not only a fan of my own club. To be only a fan of one's own club exposes one to the risk of becoming chauvinist, fanatic, nationalistic, fideistic and so on. I do not want to say that we do not have the right to support our own team. But what is here at stake is not to love one's own single club, but to love soccer. In theological terms, that means that it is not my confession, or my theology, or my own school of thought that is the essential object of the discussion. What really matters is the meaning of faith for humanity as a whole and for the whole world. What really matters is the universal truth, not the particularity of Christianity, church, Christian faith, or theology. What is at stake is the universal validity of the truth we confess in Jesus Christ. Such validity cannot be established by a mere witness; it must be validated in the forum of public discussion, life and society.

Corinna Delkeskamp-Hayes insists on the large consensus between the authors of the previous issue, and she locates this consensus in the "ultimate irreconcilability of Christian and secular ways of life" (2005, p. 122). I agree of course about the fact that a certain irreconcilability always existed and will probably always exist. But to call it "ultimate" seems to establish the position of the believer in an absoluteness and to condemn the position of the secular man to the alternative of remaining closed to every kind of belief, openness, or possibility of transcendence. The dualism of such a positionalism reminds me of the most caricaturing understanding of 
Karl Barth's theology. It is indeed only in vulgar and common Barthianism that one finds such an absolute dualism between faith and world, Christian and secular ways of life. But already in Barth (see Müller, 2005) and much more clearly in such post-Barthian authors like Bonhoeffer, Tillich, or Pannenberg, one can read and understand that dualism is never a convincing and successful solution in Christian theology and ethics.

"Traditional Christianity" seems to offer a comfortable and consoling nest, but in fact it is an ahistorical, unrealistic, and irresponsible position. I will try to develop and justify this very strong and intentionally provocative contention.

\section{DISCUSSING SOME POINTS WITH TRIS ENGELHARDT}

Let us concentrate on the seven concluding theses of Tris Engelhardt's article in the issue of Christian Bioethics on "Sin in Bioethics."

1. It is true that "absent an appropriate relationship to the Creator-God, morality cum bioethics is plural." But it is nevertheless also true that morality cum Christian theology, or Christian bioethics, remain always plural. I can share with my good brother Tris the deepest communion in God, Father, Son and Spirit; even if am (as I indeed am) a Trinitarian theologian, that does not mean 1) that I should share the same Trinitarian theology with him; 2) that my interpretation of the theological function of the doctrine of Trinity for ethics and bioethics should lead me to accept Engelhardt's theological theory of Christian bioethics, nor that I should accept all the practical consequences Engelhardt has decided to draw from his own theological and ethical theory. For example, I can be a Trinitarian theologian (as I am) but not follow Engelhardt's conclusions on abortion or homosexuality (and in fact I have written and taken position on these topics with quite different results). Trinitarian theology does not need to be traditional or lead to traditional conceptions of ethics or bioethics. On the other side, not every modern Protestant theologian (as I try to be) should be exposed to the charge that he is not a true follower of Christ or a legitimate adept of the Trinitarian doctrine.

2. It is also true that "absent an appropriate relationship to the Creator-God, the requirements of the good and the right can be in an irresolvable tension." But 1) Who decides what is an appropriate relationship to God the Creator? It is certainly not the job of the Christian thinker (theologian or philosopher) to assume that authority, because in doing so he would fall prey to a very naive and dangerous positionalism. One of the worst "sins," for the apostle Paul, was "kaukhema," the way the charismatic members of the community of Corinth were tempted to believe they alone were in the truth of God (cf. I Corinthians 1:29); 2) There is, 
indeed, no doubt at all that the secular project of modernity, as it is described by Engelhardt, leads to such an "irresolvable tension." And I do not want to say that there is no significant or even huge, decisive difference between such a secular vision and the Christian vision. The problem is rather that I cannot share at all Engelhardt's theological vision of the Christian faith in its relationship to modern reason and secular life! For me, theology is always (as also shown by Engelhardt and Hauerwas, despite their claims!) an ongoing and contemporary elaboration of the meaning of faith for today's world. Theology has always to do with practical hermeneutics in the framework of modern realities and ways of thought. No nostalgic return to traditional Christianity or to classical doctrine makes sense, absent a critical and cultural engagement with our modern questions and ways of thinking. So theology itself, theological ethics in particular, always have to do with "irresolvable tensions." It would be a sheer illusion to believe that theology means the end of tensions, or it would be theologia perennis beatorum, not theologia peregrinans viatorum! The very fact that we do theology and ethics as travellers in the human world urges us to adopt an historical theology and an incarnate ethics. Secularism is not a good thing, but Christian ethics today has to be plainly secular and worldly, in the name of Jesus of Nazareth, the Crucified, whom we confess as the Christ and whose return we await in the strength and the joy of the Holy Spirit. To wait and to hope for the Kingdom of God does not mean the end of the irresolvable tensions that we still experience in the fields of applied ethics and bioethics. There is no unified, coherent, definitive and unanimous vision of Christian bioethics today; as Christians, we have to live, honestly, openly, faithfully, hopefully, the tough reality of the conflict of interpretations. I am for the right to abort, for a just solution offered to homosexual couples in society, against the legal permission of euthanasia, etc. That does not separate me from the common faith of my Presbyterian church and from the universal Church of Jesus Christ. I am in communion with Christians all over the world, even if we do not agree on abortion, homosexuality or euthanasia, because faith-real faith-is much more than just ethical correctness. And because ethics requires a free discussion, not any sheer deduction from the Bible, from dogmas or liturgy. Ethics is always risky, and must survive under the conditions of "irresolvable tensions."

3. "Absent an appropriate relationship to the Creator-God, Who is the origin of all that is good, right, and virtuous, and Who is the final justification for interest in the good, the right, and the virtuous, as well as the ultimate motivation for moral action, urgent concerns for prudence can trump the requirements of morality." This proposal is true for Christians, inside the domain of faith and Church, but it has to be put to public debate if it is to concern all people. A theological proposal from inside (intellectus fidei) remains just a proposal, if it is not at least the object of a public, open 
and critical discussion. It is not simply a question of rational verification, but also, and more deeply, a question of credibility and plausibility: we must love also our non-Christian brother, and to love our brother means also, on a theological level, to enter into his critical questioning of the Christian faith!

4. "Absent an appropriate relationship to the Creator-God, informed by the pursuit of holiness and the avoidance of sin, one will not come fully to recognize morality's proper content (i.e., outside of the experience of grace, the uncreated energies of God, it will often not be clear, for example, that all abortions are equivalent to murder, all sexual activities outside of the marriage of a man and a woman are morally forbidden, and all physician-assisted suicide is deeply wrong." That can be true (but is not in all cases true) from inside the faith and church, but it is possible to contest some of these affirmations. Appropriate relationship to God, Christ or Spirit, if really appropriate, is a subjective quality of the Christian believer and cannot be imposed, verified or tested from the outside. And what does "avoidance of sin" mean, theologically speaking? We must try, as believers, to avoid sin in the moral sense, but we cannot avoid being sinners, who need to be justified by faith and by grace, not by moral achievement. Of course, I know that I am expressing here my Protestant (Lutheran and Reformed) conviction, but I still hope that this position has a deep connection with the teaching of the New Testament, from Jesus of Nazareth (see Gospel of Luke 18:9-14) to Saint Paul, at least. In this tradition, holiness is much more than morality, and morality is more human and limited. What we need today is a critical theological decentration of ethics, not a moralistic confusion between ethics and holiness. Christian ethics has to be modest, on the concrete level of practical advice and counselling, because Christian ethics has always to do with justification by faith and by grace, not with an excess of moral rules and norms.

5. "Since an appropriate relationship of humans to God is a necessary condition for rightly ordered moral knowledge, and since such a relationship to God is achieved in its fullness only in worthy Eucharistic participation in the Divine Liturgy, it follows that the requirements of ritual purity for worthy Eucharistic participation specify the full conditions for acquiring the full and correct content of morality and bioethics (which at their very core must be concerned with the avoidance of sin and the pursuit of holiness), thus serving as a cardinal heuristic for disclosing an adequate moral epistemology. This is the case because right worship transforms the participant not just through its pedagogical force and content (i.e., through orienting the participant in the cosmos) and through its ascetical direction (e.g., through disciplining the passions so that concentration on loving God and neighbor is not distorted, that is, so that conscience does not fail correctly to recognize the full and correct content of morality and 
bioethics), but also and most importantly through offering the participants the possibility of an experience of God and His will ("Blessed are the pure in heart, for they will see God' [Matthew 5:8])." This whole beautiful sermon is maybe valid for Orthodox Christians, but it has to be put to discussion. My main difficulty, I must admit, is with the ideal of ritual purity. In this very particular and limited theological and ethical model, there seems to exist a deep and indivisible connection between moral purity and ritual purity. For the Protestant (Lutheran-Reformed) tradition to which I belong ${ }^{3}$ and which I try to reinterpret freely for our time (see also Gestrich, 1996), the ideal of moral purity is an illusion, quite contrary to the liberating spirit of the Gospel of grace, and so it is with the ideal of ritual purity. In the Gospels, we learn how Jesus was opposed to every kind of external purity, moral or ritual, which he interpreted as a false attitude, the moral and spiritual attitude of the Pharisees (not the real Pharisees, but the so-called pharisaic attitude, which, as we all know, can be very active and present among Christians of every confession). If the word "purity" has something to do with "faith, love, and hope," we must admit that only internal, or better inner purity is able to reach the mystery, the depth and the beauty of our Christian life and of the ethical and practical consequences of such a life within society and the large world.

6. "Since worthy Eucharistic participation in the Divine Liturgy requires preparation involving rightly intending and rightly acting, the requirements of ritual purity not only sum up the conditions for acquiring the full and correct content of morality and bioethics, they sum up as well the full and correct content of morality and bioethics themselves (i.e., meeting these requirements, avoiding sin and pursuing holiness, allows a worthy approach to Eucharistic union with God in divine worship)." I can understand that a kind of inner purity may sum up the conditions for securing the right access to morality and bioethics, but I would deny strongly that this purity could exhaust the correct and full content of morality and bioethics as well. Such a nonhistorical and noncontextual conception of morality and bioethics disregards that Christian ethics and bioethics have to interpret the contemporary ethical and bioethical questions of everybody and not just to guide the particular Christian conduct of some individuals. Engelhardt is certainly right if he considers only the narrow scope of Christian individual spirituality, even if we could very well accept that other Christians adopt other sorts of moral habits or actions. But Christian ethics and bioethics have to answer in view of the challenges posed by the larger scope of social and political ethics. It is not enough to express what Christians should do; it is also necessary to say what Christians and others (believers or not) should do together, as "moral strangers" but also as moral companions, in one common and mutually supporting society. 
7. "Because right worship is a requirement for right knowledge of appropriate, that is, moral action, and because right intention and action (i.e., a moral life) are conditions for full participation in right worship, there may seem to be a hopeless circle of interdependence of conditions, in that morality would appear to be the condition for knowledge of morality; this circle is broken by repentance and grace, for in turning repentantly to God and away from sin one is able through the energies of God to enter ever more worthily into right worship, and in right worship through grace gain a fuller knowledge of the basis of an ever more complete repentance in the pursuit of holiness and the avoidance of sin." I really admire this magnificent avowal. Better late than never! Tris Engelhardt has very well seen the danger of his own position, the danger of moralism. To call to repentance and grace is very good, but this move comes too late. Grace should be invoked from the very beginning, if repentance is to be understood in a deeper than simply moral sense. The theological category of repentance must not be limited to a change in moral attitude. On the basis of a theology that affirms justification by faith alone, metanoia encompasses, beyond a merely ethical reorientation, a turning from self to God, a willingness to hear and to understand, and an entering into the dynamism of faith.

So we could agree, Engelhardt and I, that repentance is the end of the road. But do we agree that grace and justification are the narrow arch and the magnificent door that opens our way and are the conditions for our moral behavior and of every possible and desirable just action?

\section{SOME SPECIFICATIONS CONCERNING SIN, EVIL AND DISEASE}

This short discussion of Engelhardt's seven theses leads me to the need of rendering more precisely my own understanding of the relationship between sin, evil, and disease.

Sin is a theological category, connected in a critical, antagonistic mode with the positive foundation of grace, justification, and salvation (Müller, 2002b). Sin is not synonymous with wrong or bad action, but sin, as a Power, is the expression of the negative side of word, man and society.

Evil has a double signification. On the objective side, from the point of view of "God," evil is the adversary of God himself, the theological reinterpretation of the metaphorical and symbolical language of "devil." Evil is the human side of the anti-divine D-evil!

But on the subjective side, from a human point of view, evil is a moral category, connected with the question of correct and just action.

Disease is not directly connected with the categories of sin and evil. Disease is a dysfunction of life and health. Disease has to do with the 
contingency, the finite side and the mortality of human life. The connection between the human meaning and the spiritual meaning of disease demands an indirect, subtle and fragile crossfertilization of human and theological ways of asking questions. Every direct interpretation of disease in terms of spirituality can be questioned: Is not such an interpretation an overtheologization of human experience? Is it really good theology to miss the point of the radical humanity of the human condition (including morbidity, mortality, and weakness)?

I have tried to defend the idea that we must deal with traditions and history in a modern way, because we live in a (post)modern world. This is an hermeneutical move. Of course, from such a reflexive move one cannot derive any hamartology! Of course I do not want to say that we must deal with the world in a sinful way because we live in a sinful world. A theology of the world is not to be confused with a theology of sin. Kosmos, in the Gospel of John, means both good creation of God and dark side of the human being! We are obliged to distinguish between the positive acceptance of the creation and the critical questioning of sin as a human rebellion against God and His will. But my point in all this contribution is that the critical questioning of sin has not to lead to a radical questioning of human rationality. Soteriology has not to lead to anti-intellectualism and irrationality, because human reason is a gift of the Creator. I struggle against the fideistic consequences of my own Barthian roots. It is clear to me that such authors like Engelhardt and Hauerwas remain in the frame of a fideistic approach of rationality. In my opinion, modernity is not only the expression of rationalism and secularism (laicism, as it is often said in French-speaking circles), it is also the expression of sound (post-Christian) rationality!

Again, this is no encouragement for dealing uncritically with modernity. Yet there is also no reason for resorting to supranaturalism when dealing with the complexity and plurality of our secular world.

A contemporary attempt to overcome supranaturalism was proposed by Pannenberg in his Anthropology (1983). Pannenberg thematizes the question of $\sin$ in direct connection with the question of human nature, and not only in the context of Christology and soteriology. He notes that Augustine of Hippo not only considered concupiscence as a consequence of sin, but also was ready to identify them (Pannenberg, 1983, p. 84). Cupiditas is for him a perverse form of love. But this profoundly Augustinian view was no longer understood by some modern theologians who understood themselves as rationalists and idealists. Richard Rothe himself confused cupiditas and sensitivity (Sinnlichkeit). Only Julius Müller was able, in a good Augustinian manner, to understand sin as amor sui and perversion of the right relationship to God. In the theological development of this starting point, Pannenberg opposed, once again, Karl Barths' supranatural, Christological-soteriological interpretation of revealed sin. (For Barth, sin can only be understood and 
expressed if we read it in the light of Revelation; there is no natural sin because $\sin$ is from the very beginning a theological-normative, not a anthropological-descriptive category). For Pannenberg, it is not sufficient to say, like Barth, that sin can only be understood by the believer. Sin is also a universal reality, common to everybody. Each human being experiences the division within himself between love of god (or transcendence) and love of himself. On the one side, the generality of sin is for Pannenberg an empirical (anthropological) fact that one can discover and even localize within human desire (cupiditas) and its consequences. On the other side, as guilt before God, sin can only be known in the light of revelation (Pannenberg, 1983, p. 134s).

Pannenberg carries on in trying to think the link between sin and disease, and he does it with the help of Paul Tillich's interpretation of disease as the disintegration of the self. Sin causes the loss of the central unity of the human organism. This theological theory of disease is deeply connected to Victor von Weizsäcker's explanation of disease as self-alienation (cf. Pannenberg, 1983, p. 138).

Once one accepts, as I do, the necessity of a correlation between the theology of sin and the experience of psychological and ontological self-alienation, one can no longer conclude that the solution to the problem of disease should be either purely medical or purely spiritual. One must admit that solutions to the problem of disease are dialectical and not unilateral. Pure science and pure medicine are not enough, but pure spirituality is an illusion. One must develop and promote a theology of correlation (even not in the limited sense of Tillichian theology and ethics), i.e. a theology of systemic and dialectical correspondences and mutual questionings between medicine, science, psychology and spirituality. One cannot hope that Christian spirituality alone will solve all medical, psychological or scientific problems. In such a perspective, traditional Christianity seems condemned to what I would call escapism or extremism.

Because extreme positions lead to a dead end, the position of traditional Christianity seems reduced to seek a refuge in liturgy and liturgical anthropology. But the theological meaning of liturgical practices would be better respected and expressed, so it seems to me, if they were integrated into a more positive understanding of the articulation of faith in the secular world. Christian transcendence has always to do with incarnation, i.e. with a concrete spiritual presence in the immanence of creation, history and human life. Disease, in this theological framework, cannot be reduced to a sheer consequence of sin. Disease is also a phenomenon of life as a fragile and imperfect, but still fundamentally good reality. Disease is not only an anticipation of death, it is also a manifestation of the good life and a place for positive experiences of love, help, tenderness and solidarity. 


\section{CHRISTIAN BIOETHICS, ASCETISM AND SECULAR LIFE}

Tris Engelhardt writes with great profoundness: "Christian bioethics is committed to helping patients to recognize how in their illness, disease, suffering, and approach to death they must repentantly turn from their sins to God in right worship and right belief" (Christian Bioethics, 11, p. 226). He interprets disease as placed in opposition to holiness. It is not my intention to negate that disease can be overcome by the way of holiness. But is it not better to think that holiness integrates, accepts, inhabits or includes also the very presence and possibility of disease as a constitutive feature of the human condition? It seems exaggerated to place disease always on the dark side of sin and rebellion. Disease, as I wrote before, can also be a tool or a path to holiness, not just an enemy or an obstacle. It has to do with the existential structure of human contingency and natural mortality.

In the much too narrow framework of traditional Christianity, every classical topic of the Christian tradition-liturgy, faith, prayer, the Eucharist, baptism, and so on-is reduced to an argument in favor of asceticism. I have at least two reasons not to understand Christianity as an ascetical religion.

First, asceticism is not able to explain the very fact of the good creation of God. The motive of asceticism, of course, is not a specific feature of Russian or Greek orthodoxy. It was also constantly present in Paul, the Fathers of the Desert, Augustine, etc., and the trajectory from Paul to Augustine has found a deep resonance in John Calvin's understanding of Christian ethics. But I think we should resist a sheer identification of asceticism and Christian faith. Christian faith has certainly some complicity with asceticism, but cannot be reduced to it.

Second, I do not see why Christian faith should lead to a negative vision of human life. My argument, here, is not limited to the dimension of creation-instead it also concerns the doctrine of salvation or redemption.

But there are theological alternatives, which construe faith, prayer, and the sacraments in terms of a wide-open door toward the secular world.

How does placing spirituality in the midst of the profane world influence our understanding of disease?

Disease can take different faces, according to the level of its seriousness. It is a much too polysemic term. Serious disease almost always happens as a perturbing event without announcement, or at least with a very little chance of anticipation.

To deal seriously and in a concrete manner with transcendence would mean, in a Christological and Trinitarian spirit, to make profound, difficult, and also joyful experiences within the contradictions and the promises of immanence, interpreted as a place of creation, salvation, and hope. That does not mean that salvation is just immanent. It means much more decisively that salvation, as the concrete manifestation of the transcendent God, 
has to be understood as the critical and dynamic assumption (see note 1). I do not mean a dissolution of transcendence into immanency, but a dialectical transformation of the created world into a world of joy, benediction and thanksgiving. Because the aim of revelation is the eschatological fulfillment of the will of the creative God, transcendence has always to do, in Christian terms, with a renewal of all things on the earth and in heaven.

According to Engelhardt, "The morality of modernity is generally not taken to require a recognition of sin, the importance of avoiding aiming wrongly at God" (Engelhardt, 2005, p. 224). He adds therefore: "Those who know that God exists and that He is the radically transcendent and omnipotent Creator recognize also that accounts of the moral life unshaped by pursuing the holy and avoiding sin are one-sided and incomplete. The creature and the creature's concerns cannot successfully be made sense of apart from the creature's relationship to the Creator. In short, morality cannot coherently make sense outside of a cardinal concern with sin and holiness" (Engelhardt, 2005, p. 224). But the entire orientation of Engelhardt's theology is clearly directed to the dimension of holiness. "Because Christian bioethics is at its core pastoral, it aims within health care at bringing humans to holiness" (Engelhardt, 2005, p. 226). My own question will start precisely at this point. I do not agree that every bioethical question must be solved, in a Christian perspective, within the scope of holiness. Holiness is a personal issue, not a clinical or a professional one. Saying that, I do not wish to suggest that a physician would leave his Christianity at the wardrobe of the hospital, before entering his office. I only say that when he enters a modern hospital, he has to accept the modern world as the place God has given to him in order to live his faith in the secular world, and not outside of this secular world. Holiness has certainly to do with secular life, from Monday to Friday or Saturday, and even Sunday is not a sacred exception, but the center of the secular world. But holiness is not a virtue for an elite, but a light shining into the world of everybody. Holiness is not meant to be reserved to the saints, but also to be shared amongst human beings and within the secular city.

In such situations as we know in clinical ethics, the theological and ethical issue is not just holiness, but holiness as a possible light to the meaning and the respect of concrete human dignity. Or, in order to clarify the two different levels: clinical ethics concerns the way in which every one's human dignity can be better respected and protected. Christian ethics provides a good justification, with the help of categories like holiness, love or hope, for the secular belief in that human dignity.

Pastoral ethics, by contrast, concerns the way in which pastors or visitors can help the patient to grow in love and wisdom-even in holiness, if he or she is a Christian believer. We should not confuse therefore the humanistic aim of protecting dignity and the spiritual aim of encouraging holiness.

But the very root of this confusion, as I see it present in the way Engelhardt speaks of sins and holiness, lies in the reduction of sins (in plural) 
to acts opposed to the will of God. Holiness here is linked too strongly with refraining from such concrete sins. As I have tried to show above, sin is to be understood on a theological level, and not on a moral one. I have the impression that Engelhardt here confuses spirituality and morality.

Sins tend to be equated with wrongful or bad acts. But in the biblical tradition, especially in the letters of the Apostle Paul, sin (in the singular) is a theological, not an ethical term. It means a false relationship to God, absence of true faith, but also the illusion that one can achieve salvation by one's own acts or deeds. Holiness comes from faith, and faith comes from God. Faith is primarily a gift, not a decision or a voluntary act.

Holiness is strongly connected with the justice of God. But this justice, which is exclusively God's own, can be granted to human beings. Faith, as an intimate or even mystical experience, is an experience of the divine gift of justice. To be justified by faith does not mean that faith is a salvific act, but that, while believing in God, I experience being accepted for what I am, a sinner, a man without God, a man against God, a man who is not acceptable in his own eyes. This spiritual experience is not the end, but the new beginning of ethical activity and responsible self-affirmation. "Decisive for this self-affirmation is its being independent of any moral, intellectual or religious precondition: it is not the good or the wise or the pious who are entitled to the courage to accept their being accepted but those who are lacking in all these qualities and are aware of being unacceptable.... It is in the experience of the Reformers the acceptance of the unacceptable sinner into judging and transforming communion with God" (Tillich, 1952, pp. 160-161).

To do theological ethics is therefore to know about the fact that, in ethics, there is also supra-ethics, promise, gift, transcendence without conditions.

\section{SOME PROVISORY BUT PROVOCATIVE CONCLUSIONS}

I conclude with some provocative consequences for clinical ethics and theological bioethics:

1. Sin should not become primarily a moral category, but remains a theological one. The victory against sin has not to do with practical holiness but with existential struggle for meaning or spiritual discovery of truth.

2. Sin is not a causal explanation for disease, but a clue to understand the contradiction of existence and an appeal to discover spiritual freedom.

3. Christian ethics should not subsume every human difficulty or disease under a question of salvation, but contribute to the meaning of human life, under the light of salvation promised, given, and contemplated.

4. It is a sign of good Christian theology not to misuse the name of God, and not to quote the Bible in every situation without any necessity because God alone is Holy-not our life, or our ethics. At least, not 
prima facie. Holiness is a good theme for Christian ethics, if we remember that we speak about the holiness of God, not prima facie about our own holiness. Human holiness may be a gift of God, but we do not have any human or psychological guarantee that we will reach it or to keep it. Holiness is an exception for us, and the rule for God. Soli deo gloria. Soli Deo sanctitas. Ethica christiana bumana est.

\section{ACKNOWLEDGMENTS}

To Tris Engelhardt, my very dear friend, for whom the critical discussion of ideas is never incompatible with love and mutual respect.

I would like to thank Corinna Delkeskamp-Hayes for her kind and efficient help in translating and for her inspiringly critical questions concerning previous versions of my text.

\section{NOTES}

1. The term "assumption" (for the French "assumption") is meant to translate the German (ultimately Hegel-inspired) term "Aufhebung," as used by Barth in his title of $\int 17$ (Barth 1939). See my presentation of this famous paragraph in Müller (2005).

2. This "positionalism" designates an attitude which proclaims someone's subjective position as absolute truth, and thereby withdrawing that claim not only from discussion, but thereby also from the chance at working out any scientific or theological objectivity.

3. I am a Prebyterian, but I am also convinced that Calvinian Reformation cannot be fully separated from the major influence of Luther; see Müller 1999 and 2005.

\section{REFERENCES}

Barth, K. (1939). Die kirchliche Dogmatik I/2, Zollikon: Verlag der evangelischen Buchhandlung, pp. 304-397.

Delkeskamp-Hayes, C. (2005). 'Between Morality and Repentance: Recapturing "Sin" for Bioethics,' Christian Bioethics, 11(2), 93-132.

Engelhardt, H. T., Jr. (2000). The Foundations of Christian Bioethics. Exton, PA: Swets \& Zeitlinger.

Engelhardt, H. T., Jr. (2005). 'Sin and Bioethics: Why a Liturgical Anthropology is Foundational,' Christian Bioethics, 11(2), 221-239.

Gestrich, C. (1996). Die Wiederkehr des Glanzes in der Welt: Die christliche Lehre von der Sünde und ibrer Vergebung in gegenwärtiger Verantwortung. (2nd ed.) Tübingen, Mohr.

Hauerwas, S. (2001). With the Grain of the Universe. Grand Rapids: Brazos Press.

Holderegger, A., Müller, D., Sitter-Liver, B. \& Zimmermann, M. (Eds.). (2002). Theologie und biomedizinische Ethik: Grundlagen und Konkretionen (Studien zur theologischen Ethik), Fribourg i. B.-Fribourg (Suisse) Universitätsverlag-Herder.

Morin, E. (2004). La méthode, Vol. 6: Ethique. Paris, Le Seuil.

Müller, D. (1999). L'éthique protestante dans la crise de la modernité: Généalogie, critique, reconstruction. Paris-Genève: Le Cerf-Labor et Fides. 
Müller, D. (2000) Les passions de l'agir juste: Fondements, figures, épreuves. Paris-Fribourg: Le Cerf-Editions Universitaires.

Müller, D. (Ed.). (2001a). 'Is Theological Ethics Relevant for Philosophers?' Ethical Theory and Moral Practice, 4(4), 329-429.

Müller, D. (2001b). 'Why can and how can religions and traditions be plausible and credible in public ethics today?' in 'Is Theological Ethics Relevant for Philosophers?' Ethical Theory and Moral Practice 4(4), 329-348.

Müller, D. (2002a). 'Les sources religieuses du soi et l'éthique de l'action juste,' Laval théologique et philosophique, 58(2), 341-356.

Müller, D. (2002b). 'La bioéthique au péril de Dieu: Pour une critique théologique de la maîtrise éthique sur le vivant,' Revue de théologie et de philosophie, 134, $327-340$.

Müller, D. (2005). Karl Barth. Paris: Le Cerf (Initiations aux théologiens).

Onfray, M. (2005). Traité d'athéologie: Physique de la métaphysique. Paris: Grasset.

Pannenberg, W. (1983). Anthropologie in theologischer Perspektive. Göttingen: Vandenhoeck \& Ruprecht.

Tillich, P. (1952). The Courage to Be. London and Glasgow: Nisbet. 
